\title{
Educational Preparation of Older Adults and Their Families for Retirement
}

\author{
María de los Ángeles Aguilera ${ }^{1}$, José de Jesús Pérez ${ }^{1}$, Diemen Delgado ${ }^{2}$, \\ Mónica Contreras ${ }^{1}$, Martín Acosta ${ }^{1}$, Blanca Elizabeth Pozos ${ }^{1}$ \\ ${ }^{1}$ Department of Public Health, Universidad de Guadalajara, Guadalajara, México \\ ${ }^{2}$ Department of Occupational Health, Clinica Rio Blanco, Los Andes, Chile \\ Email: aaguileracd@hotmail.com,jjesusperezs@hotmail.com,diemen.delgado@clinicarioblanco.cl, \\ monicaudg@gmial.com,fmartin63@gmail.com, litaemx@yahoo.com.mx
}

Received July 23 ${ }^{\text {rd }}, 2013$; revised August $23^{\text {rd }}, 2013$; accepted September $1^{\text {st }}, 2013$

\begin{abstract}
Copyright (C) 2013 María de los Ángeles Aguilera et al. This is an open access article distributed under the Creative Commons Attribution License, which permits unrestricted use, distribution, and reproduction in any medium, provided the original work is properly cited.
\end{abstract}

\begin{abstract}
The purpose of this qualitative case study, carried out in two phases, is to systematize the learning experiences and expectations of older adults and their families as they face approaching retirement, in Guadalajara, Mexico, 2012. The strategy implemented was an educational preparation for retirement. Six adults had already retired, two were soon to be retired and eight family members were chosen for this study. Data were collected using semi-structured interviews and a SQA-E format. The educational strategy was an interactive conference. A phenomenological analysis was made of the experiences recorded. The naturalistic criterial evaluation of learning experiences and expectations was applied before and after the educational intervention. Through this intervention, participants were made conscious of their problems, expressed the desire to improve certain aspects of their lives and continued educational preparation.
\end{abstract}

Keywords: Preparation; Sensitization; Older Adults; Retirement; Family

\section{Introduction}

Retirees and adults (not yet seniors) make for a vulnerable high-risk population. Educational intervention is very important for them to prepare for the next stage of their life and prevent health risks.

Retiring was a non-issue in the past because life expectancy was short. Now this is a fundamental issue for the number of people affected and for many years when they will live as retirees. A third of retirees experience changes in their health during the first six months, solve the problem for so many months, or their problems may last up to two years (Moragas, Rivas, Cristofol, Rodriguez, \& Sanchez, 2006). Others, who apparently had no initial adjustment problems have problems at this stage of disillusionment (Atchley, 1971), as knowledge and skills needed to deal with the changes positively.

One of the central themes of the Second World Assembly on Ageing in Madrid, Spain was to propose that older people should participate fully and effectively in the economic, political and social development of their societies (Organización de las Naciones Unidas, 2003).

However, during the transition from work to retirement, in most developing societies, preparation is very scarce and social rites are almost nonexistent (Moragas et al., 2006), leaving people disabled for social participation.

The task of educational preparation for retirement is not easy. There are few empirical references that would illustrate this. In theory, andragogy is defined as the set of fundamental principles for adult learning that applies to all learning situations (Knowles, 2006) and participatory models of educational inter- vention (Gleibler \& Hege, 1997; Pérez, 2003; Rodríguez-Sedano \& Solés-Elizalde, 2008), and its fundamentals are more suitable for educational strategies with older adults.

However, there is still a need to test the educational models in practice to build one's own retirement educational mode to help improve the quality of life for seniors and their life partners. The population of retired people is heterogeneous and each person, or a group of persons, according to the combination of their personal, social, employment and retirement factors, have diverse needs in retirement from employment. On the other hand, it is important to engage close relatives of the retirees in educational training processes for daily living. In that case, the heterogeneity of the retired population meets the plurality of characteristics of their families.

Despite these inherent difficulties, preparing for retirement should be addressed urgently since its seriousness warrants it. People who have difficulty in adjusting to retirement suffer physical alterations (insomnia, hypertension, digestive and cardiovascular disorders), psychological problems (anxiety, pessimism, depression, alcoholism, and reduced libido) and social problems (loss of relationships and loneliness), which are collectively called the "Retirement Syndrome" (Moragas et al., 2006). Also it was found that some retirees and early retirees experience stress, dependency and domestic violence during retirement (Aguilera \& Torres, 2008).

Although there are at least seven scientific theories of human development that (Friedman \& Havighurst, 1954; Cumming \& Henry, 1961; Havighurst, 1994; Atchley, 1971; Freud, 1973; Baltes, 1989; Carstensen, 1992) have pertinent suggestions for 
preparing successfully for retirement (Limón, 1993; Madrid \& Garcés, 2000; de las Heras, 2004), most of them have not been used yet in most of the Latin American contexts, or at least not systemically.

Unlike many studies that have been made on the economic, physical, psychological and social problems that retirement has on people, there are very few studies about the effects of preparation programs for retirement (Skoknic, 1998; Pérez et al., 2006; Moragas et al., 2006).

Preparing for retirement should be tailored to employees, considering all the intervening factors as far as possible. It should include the contributions of the various theories that explain retirement and the findings of empirical studies (Aguilera, 2010) and be based on one or several educational theories.

However, before preparing for retirement, you must carry out a process of educational awareness in participants, with the intention of motivating a process of individual and collective reflection on their role in the issue of retirement.

Raising awareness is a key enabling subsequent educational activities (Chicharro \& Maza, 2008). In that sense, the purpose of raising awareness in older retirees is to enable them for social participation.

Sensitization is planned according to the experiences of the subjects and is aimed at helping to decipher the source of the problems, raise critical awareness and generate interest in practical solidarity and active engagement with changing mindsets, attitudes and practices. With awareness we can understand the source of the problem and enhance the understanding of the causes (eQual, 2011).

Brief intervention programs, such as interactive lectures, can have results comparable to longer programs as major changes may promote a greater awareness and sensitization to certain problems. Social awareness through interactive lectures facilitates the abandonment of myths and false beliefs regarding the causes of the problem (Pick, Leenen, Givaudan, \& Prado, 2010). Conferences may involve both older adults and their closest relatives, with the intention of improving the latter's' understanding of the issues facing retired employees.

The first step in educational knowledge is a diagnosis to become acquainted with the people, trying to meet their interests and needs. Having a good initial diagnosis facilitates the following steps and makes receptiveness to change a true success (eQual, 2011).

It is considered that an appropriate way to diagnose people is to access their own voice, through phenomenological exploration for the purpose of describing, theming and interpreting their experiences and subjective experiences (Husserl, 1972). Using this form of qualitative research is useful because it allows us to learn from the voice of the people affected, from the emic perspective (Aguilera \& Torres, 2008; Delgado Aguilera, Delgado, \& Rugs, 2012).

Based on this qualitative diagnosis, you can define the objectives of the conference along with data awareness, information and research that support the arguments to be presented. The next step in educational awareness is for participants to selfassess their knowledge and expectations, both before and after implementation of the interactive conference. It should be clear in the self-assessment about what, where, when, for whom, why, how and what is being assessed (Castillo \& Cabrerizo, 2004). It is advisable to employ qualitative techniques to evaluate educational interventions which were applied to a small number of people (Aguilera, Acosta, \& Pozos, 2010).
Based on the above, we carried out this study with the overall objective of systematizing experiences and learning of older adults and their families before and after implementation of the education strategy to raise awareness of retirement, in order to provide useful information for social interventions after the educational preparation for retirement.

\section{Methodology}

\section{Type and Design of Study}

We conducted a qualitative case study design, both descriptive and interpretative, in two phases. Both the diagnosis and the evaluation sought the participants' subjective knowledge through comprehensive tools (Morse \& Field, 1995; Patton, 1987; Pérez, 1994; Taylor \& Bogdan, 1992; Wilson, 1991).

The case studies were defined as empirical investigations of a contemporary phenomenon within its real-life context when the boundaries between phenomenon and context are not clearly evident, and in which there are multiple sources of evidence that can be used. This entailed overall understanding, comprehensive description and analysis of a situation as a whole and in context. The case studies are compelling and capture the readers' attention; they have a different type of awareness as a general purpose (Yin, 1989; Stake, 1995; Morra \& Friedlander, 2001).

The first phase, conducted prior to the implementation of the conference, explored the activities, attitudes, values, emotions and sensory perceptions (Patton, 1990), in relation to the topic of retirement. All this was through the existential phenomenology of time, space, and corporeal commonality (Husserl, 1972; Maffesoli, 1997; Merleau-Ponty, 1985). It also led to the selfassessment of knowledge and expectations on the same subject. In the second phase, carried out at the end of the conference, the participants self-assessed lessons learned and new expectations.

\section{Spatiotemporal Boundaries}

The spatial delimitation of the study was implemented in the city of Guadalajara Jalisco Mexico. The temporal limitation was the month of June 2012.

\section{Participants}

16 people, six of whom were elderly retirees, two seniors nearing retirement and eight relatives attended (see Tables 1-4).

\section{Theoretical Sampling}

We used non-probability sampling theory for convenience in the selection of the participants. From a general population of volunteer subjects who attended the conference, we intentionally selected cases that met the inclusion criteria (Patton, 1990). These criteria were being retired or elderly before retiring in a period not exceeding five years, going with a free form relative to the conference, and who wanted to participate along with their family, voluntarily for the study.

\section{Techniques for Obtaining Information}

\section{Semi-Structured Individual Interviews}

They were useful for obtaining data on the experiences of individuals regarding retirement and preretirement, as the case may be. They were done between 15 days and one month be- 
Table 1.

Description of older retirees.

\begin{tabular}{cccccccc}
\hline Elderly retired adult & Time retired & Age in years & Sex & Marital status & Number of children & Diseases & Occupation \\
\hline Moon & 6 years old & 69 & Female & Widow & 3 & High blood pressure & Clinical laboratory technology \\
Land & 19 years old & 75 & Female & Widow & 7 & High blood pressure & Employee \\
Venus & 3 months & 64 & Female & Maiden & 1 & None & Secretary \\
Sun & 9 years old & 73 & Male & Married & 3 & High blood pressure & Manager \\
Mercury & 11 years old & 71 & Male & Married & 4 & Renal failure & Merchant \\
Neptune & 11 years old & 74 & Male & Married & 6 & Digestive disorders & Architect \\
\hline
\end{tabular}

Table 2.

Description of older retirees' families.

\begin{tabular}{ccccccc}
\hline Elderly retiree's family & Relationship with & Kinship & Age in years & Sex & Diseases & Work activity \\
\hline Galaxy & Moon & Granddaughter single & 18 & Female & Asthma and allergies & Student \\
Pluto & Land & Son-in-law married & 57 & Male & None & Doctor \\
Mars & Venus & Single son & 29 & Male & None & Employee and student \\
Miranda & Sun & Wife & 68 & Female & None & Housewife \\
Comet & Mercury & Wife & 67 & Female & Diabetes and hypertension & Housewife \\
Andromeda & Neptune & Wife & 70 & Female & Diabetes & Housewife \\
\hline
\end{tabular}

Table 3.

Description of seniors nearing retirement.

\begin{tabular}{cccccccc}
\hline Nearing retirement & Time until retirement & Age & Sex & Marital status & Offspring & Diseases & Occupation \\
\hline Jupiter & 1 year & 64 & Male & Married & 3 & Digestive disorders & Manager \\
Star & 5 years old & 58 & female & Widow & 1 & None & Psychologist \\
\hline
\end{tabular}

Table 4.

Description of families of the seniors nearing retirement.

\begin{tabular}{ccccccc}
\hline Family of senior nearing retirement & Relationship with & Kinship & Age in years & Sex & Diseases & Occupation \\
\hline Polar bear & Jupiter & Wife & 64 & Female & Hypertension and leg pain & Merchant \\
Uranus & Star & Single son & 14 & Male & None & Student \\
\hline
\end{tabular}

fore the conference with both older adults and in family.

They were made pursuant to the design of four interview scripts with questions that generated information from the activities, opinions, meanings, values, feelings, sensory perceptions and context of the people.

Most people preferred to answer the interview in writing, arguing that they could read, reflect and fill it in stride. The researchers went back to their homes after a couple of days and delved into the aspects considered important in looking for comprehensive understanding.

\section{Awareness Strategy}

The conference "Understanding My Retirement" was the sensitivity strategy used. Its design was based on data, information and research on the issue of pensioners. The content covered the definitions of retirement, factors involved in retirement, retirement effects on health, political and economic situation of pensioners, contributions of science in the field of pensioners, scientific theories, empirical studies, local research conclusions and practical suggestions for those involved in retirement. It lasted two hours.

The conference was interactive. Progress was made accord- ing to the interest of the participants. When they considered it necessary, they would interrupt the speaker to discuss some personal experience or express some opinions and/or concerns. Upon completion of the educational activity, there was a simple toast where seniors and their families could spend time with the investigators.

\section{SQA-E Format}

The SQA-E format was used as a tool for cognitive matte for participants to gain self-knowledge and learn their expectations. We used it just before the conference to start awareness by filling in the first two columns. The last two columns were answered by people at the end of the conference.

Participants shared their knowledge and expectations before and after the conference at two plenary sessions. The initial plenary session led to a pleasant work environment (see Figure 1).

\section{Data Analysis}

We performed qualitative data analysis in both phases of the study. In the first phase phenomenological analysis was per- 
Topic: Understanding my retirement

Instructions: Please complete the first two columns before participating in the Conference. You must fill the last two columns at the end of the Conference. Thank you.

\begin{tabular}{cccc}
\hline & Name: & Date: & \\
\hline Se & Quiero saber & Aprendi & Expectativas nuevas \\
$($ I know $)$ & (Will know) & (I learn) & (New expectatives) \\
\hline
\end{tabular}

Figure 1.

Format SQA-E.

formed on the data gathered through semi-structured interviews. The theoretical basis for the analysis of the experiences was phenomenology, understood as the description of the experience without resorting to causal explanations (Sandoval, 2002), and the phenomenological method at stages of description and interpretation theming (Lanigan, 1997), whose purpose is to explain human subjectivity and interpretation that he/she makes of his/her social world. The concept of the experience is the basis of the framework for the understanding and analysis of human reality (Sandoval, 2002).

The categories of analysis were subject, subjectivity, meaning, interiority and experience, seeking relevance and significance. The four basic existential phenomenological analyses are space lived (spatiality), body lived (corporeality), time lived (temporality), and human relations lived (relationally or communality) (Sandoval, 2002).

First was the description of the findings with the same words used by the participants. Subsequently, the stories underwent thematic analysis, seeking relevant phrases, naming codes and integrating code families. Finally there was the interpretation of data. Operational support used was the Atlas.ti version 4.1 software for Windows 95 or later.

The second phase of the study was an assessment of the participants' knowledge, lessons learned and expectations. The self-assessment had its foundations in theoretical models directed at the judgment of merit or worth (Castillo \& Cabrerizo, 2004), specifically in the naturalistic criteria evaluation model (Guba \& Lincoln, 1989) and the model focused on the needs of the people who participated (Stake, 1995). The evaluation process included gathering the claims, interests and needs. Initial diagnosis had a moment (before the conference) and the final summation (at the end of the conference). Given that extent was partial, it focused only on participants' knowledge and expectations (Casanova, 1999).

\section{Ethical Considerations}

Ethically, research was subject to the Guidelines of the General Health Law in the Field of Health Research in Mexico, Title II, entitled “Ethical Aspects of Human Research”, Chapter I, in accordance with Articles 16-19 and 23 governing research considered safe.

Participants learned about the objectives of the study and gave their oral informed consent. Also group participants were protected in accordance with the Helsinki Declaration (Asociación Médica Mundial, 2008), in its current version. Furthermore, the Coordinating Office for Master of Science Program at the Occupational Health Center, University Center for Health
Sciences, University of Guadalajara, reviewed the study and gave it final approval.

\section{Findings}

\section{Experiences of the Participants}

In the analysis of the participants' experiences in dealing with retirement and preretirement, we found 12 families of codes: living environment, daily activities, stories, knowledge and opinions about retirement, emotions, life values, bodily experiences, relationships experienced, length of their lives, sense experience and general appreciation of life.

These 12 families were grouped into one of four basic themes existential corporeality, commonality, temporality and spatiality in order to make a description and phenomenological categorization of themes.

Existential corporeality consisted of the families of daily activities, emotions experienced and bodily experiences. The commonality grouped existential knowledge about retirement, life values and relationships experienced. In the basic existential temporality, time they have lived, appreciation of life and views on retirement were explained through their surroundings, their sensorial experience and anecdotes about retirement.

Within each basic existential factor, in addition to describing the integrating families, the cases are described according to the four types of participants in the study: retirees, families of retired people, people nearing retirement and relatives of people approaching retirement.

\section{Corporeity in Participants}

Among the activities of retired people we found taking care of grandchildren, household chores, watching TV, and feeding and taking care of pets in the case of the two widows. Both considered they were very happy. Earth remained active at home and felt healthy. On the other hand, Moon had her daughters and grandchildren at home during the day, but slept alone and felt afraid and sad. She mentioned that she missed social life outside her family, felt tired and the loneliness of widowhood weighed on her. The son, granddaughter and son-in-law realized that they did not have a habit of looking at the body of retired ladies and had not heard any complaints or comments from them.

Venus, a recently retired lady, was found still working in the same place as usual, but without pay. She had made a deal with her boss to arrive two hours later than usual (11:00 am) and not leave until the evening. She lived in conflict because her fellow workers did not like to see her still there, taking up space that they wanted for themselves. However, she preferred living in constant conflict, believing that retirement meant going home and working harder. She said she did not recognize any emotional or bodily change, although we researchers perceived frustration and negativity.

The retired gentlemen recognized that retirement had affected them but they had found a way to compensate. Sun and Mercury returned to work in informal commerce after retirement. Neptune was dedicated to taking care of his family, taking his wife to doctor appointments, to being a minister at church, walking, and at least once a week frequenting friends who had not died yet. He acknowledged that he had not overcome the crisis of "assimilating it and not a wage earner". As for their bodies, the three retired men reported feeling "Dete- 
rioration characteristic of their age" and feeling tired. Their wives agreed that they had observed the same. Still, the retired men recognized the value of being active while they still could.

Family members of retired persons generally expressed that they continued doing the same activities as before their relatives retired, especially in the case of wives (at home), the son (work-study) and the son-in-law (work). The granddaughter was studying and taking care of her grandmother Moon. The feelings of all the retirees' families were positive due to their greater personal convenience. They said they felt happy with peace and quiet while the family felt less pressure and stress.

The pre-retiree, Jupiter, said he worked hard both in his own business (afternoon and evening, including weekends) and as an employee (morning and afternoon). He also took care of his three granddaughters. His feelings were of uncertainty and anxiety. He felt very tired and under pressured.

Polar Bear, Jupiter's wife, worked at a very fast pace seven days a week at her local handicraft store while taking care of three granddaughters. She said she was happy and eager to see her husband relaxed. She felt very tired and nervous about "the retirement”. Her legs ached and she had very strong colitis.

Pre-retiree Star worked and enjoyed eight hours in the morning and in afternoon tried to relax, partaking in religious activities, reading and watching her diet. Her emotions were melancholic, joyful, emotive and awareness. She felt hormonal changes in her body and a tendency towards sedentarism. Her son Uranus was studying as he had always done. He felt happiness, appreciation, understanding, dedication and wellbeing upon imagining his mother retired. His mother's body seemed to be like always to him, without any problems.

\section{Commonality Participants}

Moon believed that at retirement she would get sick or have family problems. Her granddaughter Galaxy said she knew almost nothing and appreciated spending time with her grandmother and seeing her relax in the afternoon. Moon no longer had a good relationship with her daughters; they were rivals for her affection to the extent that she became very mortified. However, Galaxy categorized her relationship with her grandmother as excellent, full of confidence and tranquility and the pleasure of sharing time with her.

Earth knew that he would live his retirement in peace without the pressure of time or people. His son-in-law Pluto said he knew nothing about the subject. They talked to each other and had a good family relationship.

Both Moon and Earth valued home ownership and retirement income to live with dignity and not rely on their children. They both attached great value to having a family and taking care of and seeing their grandchildren every day, they no longer could take care of their own children.

Venus revealed that she had very little knowledge about retirement. On the other hand her son Mars clearly knew that retirement was a goal of years of working for pay. Venus appreciated not having to follow an inflexible schedule. Her son wanted her to stop going to work, to see her rest emotionally from the stress of the office. Both recognized that they had a good relationship with each other

Sun said he had a pleasant experience in retirement because he had tried to do what he liked after retiring. His wife Miranda shared that knowledge. Sun appreciated that his time was now his own and he was not accountable for anything. But he confessed that he had isolated himself from friends and family.
Mercury and his wife Comet said they had no knowledge about retirement and that they had a good relationship. Mercury valued the time he could work despite having a kidney disease. His wife appreciated that he was happy.

Neptune said he knew that retirement would cause crisis due to the change and to the deterioration of his health, because he had a daughter who was a psychologist who had warned him. His wife, Andromeda, acknowledged she had some knowledge because she had read some books and listened to talks. Neptune valued his relationship with Andromeda, his children, grandchildren and friends, and said their relationship was intense, positive and growing. She shared the new integration of their marriage, family and social contribution through the Church.

Jupiter said he had only general information and Polar Bear said she knew nothing. Jupiter appreciated he would have more time to share with his family. Polar Bear appreciated that they would be able to get up a little later and they would have time to relax. Jupiter felt he had a good relationship with his family that encouraged him to retire. On the other hand, Polar Bear felt that her relationships were a little strained by his nervousness, and she was concerned about everything she had had been told would happen at retirement.

Star and her son Uranus both knew that they would receive a monthly payment with a proportionate share of their Christmas bonus included. Star now appreciated her co-workers more and tried to be active throughout her workday. Her son wanted to see her relax. They perceived their relationship as good and close.

\section{Temporality Participants}

Earth and Moon perceived that they would not have enough time for everything they wanted to do, but that the time available would allow them to live peacefully. Earth felt well without the pressure of work or the arbitrary orders of his boss. Moon felt that she had retired at the right time: "When my sicknesses and pains became evident, I prepared ahead of time and arranged everything."

This was more relaxed time for Galaxy since her grandmother was at home because according to her, her grandmother Moon no had kind of cares and was rested.

Venus considered living her new time with the ability to get up a little later, which made Mars feel relaxed. Venus admitted that she had decided to keep on working for a while by choice, although she was not compensated economically. She said that it was hard to leave a lifetime of work in such a short time.

Male retirees and their spouses shared the impression of living in a very fast, very active time where the days are short but they made the most of the time they had. Andromeda said retirement had been an opportunity to learn and adapt. She felt that life was very good because she was with her husband all the time, and they talked more; they helped each other and looked out for each other.

Sun said that when he retired he could have still worked for more years with the same enthusiasm. Mercury acknowledged that his retirement was timely and very good because it gave him time to continue working on something else. For Neptune, retirement had been an opportunity for growth.

Jupiter thought about the future and imagined a better time to relax and have fun, traveling continuously. He said he was experiencing uncertainty because it was not clear what would happen to him and his health once retired. He believed he should prepare mentally to accept that it was time to end his 
active and regular life but he could start a new life. Polar Bear said they had talked a lot about the time they were going to have Jupiter would help her in her business and they would have more time to sleep. She wanted her husband to learn something related to the candle business they owned so he could have extra income. She opined that retirement was most appropriate for Jupiter, because he seemed very tired and stressed to her.

Star lived in the present and saw that time had passed by faster over the years. She had studied for a Masters in research years ago to be able continue working intellectually and feel productive. She was aware that she was near the end of her working life after 27 years. She saw it as an achievement and would remain active on something else. Uranus saw no change in his perception of time but liked the idea that when his mother retired, she would be with him for more time, because she had worked all her life.

\section{Spatiality in Participants}

Earth said she was happy in her living environment i.e. fulltime at home although she revealed that initially she was sad and sick. But it seemed nice to go to her grandchildren's festivals and be with her children at events: "I saw I had the freedom to go anywhere”. Pluto said he had seen that retirement put people in a better mood, rejuvenated.

Although Moon lived the same environment, she said yes, at first she was happy at home, but over time she missed hanging out with her coworkers but not so much the work. But then came the quiet. And now there was not enough time to do all housework. She narrated that now that she had retired she had enjoyed her grandchildren and had seen them grow: "On the other, I did not spend time with my daughters their teenage years because I worked all week and even on Saturdays and Sundays. I had to raise them myself and I lost out on many stages of their life." She acknowledged it was good to make way for younger people and put on a good face at this stage. Galaxy said she saw how her grandma cooked and learned from her.

Venus said her everyday surroundings were like before she retired because she was still going to work and was not at home, but there was a lot of conflict in the work: "I keep on fighting the same with my co-workers because they do not know how to do things properly."

Sun and Mercury's living environment was active. Sun said that his business was his usual environment but for his wife, the environment was tense, because she felt the constant presence of Sun outside the home.

Retirement had not meant anything extraordinary for Mercury because the next day he began to work on his cardboard packaging business. He said he had heard that several people he had known lamented the poor retirement pension they received.

Neptune said he was at home almost all the time. When asked what his living environment was like, he said: "Changing and increasingly reclusive." He said that right after he retired, he tried to start a business with one of his children but it did not work out and he chose not to work anymore. Now he feels excited about travelling, visiting places, people and food.

The wives of the retired gentlemen commented that what had struck them most about their husbands' retirement was that they were at home more. Unlike Miranda, Andromeda said that she had recovered her husband and was no longer alone.

Jupiter perceived an environment of stress and pressure from family, justifying that maybe he unwittingly showed his fatigue, anger and temper, and his behavior towards them told them he needed to retire. Polar Bear confirmed that her family was waiting for husband to retire: "Even the kids would say it's time to relax. We will do better in the store with your help and we will get out more out $t$. My kids joke that I'm going to work more now." Jupiter said he was shocked by discussions or comments of some people. He had heard that some people died when they retired due to inactivity. Polar Bear heard that retirees are depressed, sick or bored from doing nothing.

Star perceived her environment aware of her upcoming retirement and she would call her friends in the afternoons to establish more personal contact because she thought she would miss her work, but especially her co-workers. She had heard that some people were organized and travelled and devoted more time to themselves and that other people were depressed. Uranus found his environment confusing because he did not know if everything would change with his mother's retirement and believed she might feel lonely and insecure, although he wanted her to be happier.

\section{Knowledge, Expectations and Reflections of the Participants}

Prior knowledge, expectations before the conference, the lessons learned, expectations and reflections at the end of the conference, are shown in Tables 5-9, respectively.

\section{Discussion}

The experiences of the participants were heterogeneous. Similar retiree experiences were found in the two widows and their grandchildren, and the two men who had returned to work. Experiences in these two groups were more positive than in the single woman and the man devoted to his home.

There were totally different experiences in the pre-retirees. The man manifested greater difficulties, fatigue and negative feelings.

Experiences were also different for relatives. Life experiences of wives of retired men generally were positive and similar. But the wife of the man about to retire was anxious. The granddaughter and adolescent showed more empathy than the other son and the son-in-law.

We agree with Moragas et al. (2006) on the importance of asking people about their experiences of living in retirement.

The contents of the lecture as an awareness strategy followed the recommendations of Limón (1993) to instill the need to learn to avail of free time, the importance of income, health care, leisure and social activities and to extend the intervention to the whole family surrounding the retiree, especially the spouse.

Some similarities were also found in the lecture contents with the training program by de las Heras (2004) such as talking about retirement as a new stage in personal development, emphasizing they are retiring from work, not from life. Regarding health care, the conference gave more emphasis to psychosocial health, and skipped the subject of the biology of aging, sexuality and health prevention as well as the issue of economic planning for retirement.

We found similarities in the sensitivity strategy with Chicharro \& Maza (2008) and Pick et al. (2010) that the goal is to raise awareness for participation for the purpose of changing behavior, attitudes and social norms. The retirees in our study 
Table 5.

Knowledge before the conference.

\begin{tabular}{|c|c|c|c|}
\hline Retirees & Retirees' relatives & Pre-retirees & Relatives of pre-retirees \\
\hline End of a phase & End of the time for work & Completion of an active life stage & \\
\hline $\begin{array}{l}\text { Start of the third stage } \\
\text { Rest } \\
\text { Tranquility and family } \\
\text { Age retirement }\end{array}$ & $\begin{array}{l}\text { It does not means giving up } \\
\text { age-appropriate activities }\end{array}$ & Jump to another calmer stage & $\begin{array}{l}\text { When you reach a certain } \\
\text { age you may stop working }\end{array}$ \\
\hline $\begin{array}{c}\text { An achievement after working most of my life } \\
\text { Time is mine }\end{array}$ & $\begin{array}{l}\text { Joy } \\
\text { Gratuity, end of a stage of life }\end{array}$ & Glee: it is a stage to enjoy & \\
\hline Adjustment risks & $\begin{array}{l}\text { Those who do not see this will } \\
\text { have died before a year }\end{array}$ & & \\
\hline Need to forecast & $\begin{array}{l}\text { You make less money } \\
\text { than before }\end{array}$ & & $\begin{array}{l}\text { No longer working gives } \\
\text { you a monthly pension }\end{array}$ \\
\hline Nothing & & & Almost nothing \\
\hline
\end{tabular}

Table 6.

Expectations before the conference.

\begin{tabular}{|c|c|c|c|}
\hline Retirees & Retirees' relatives & Pre-retirees & Relatives of pre-retirees \\
\hline $\begin{array}{l}\text { Everything. I want to know, what I want to say, } \\
\text { what you know and you want to tell me }\end{array}$ & $\begin{array}{l}\text { Everything mentioned is important } \\
\text { and interesting to me. }\end{array}$ & & $\begin{array}{l}\text { All matters relating } \\
\text { to retirement. }\end{array}$ \\
\hline $\begin{array}{l}\text { What I can do because I did not prepare in time. } \\
\text { I hope they talk about how you retire, because } \\
\text { sometimes you do not know anything. }\end{array}$ & $\begin{array}{l}\text { What retired people can do to } \\
\text { not feel overwhelmed. }\end{array}$ & $\begin{array}{l}\text { I want to know what I should } \\
\text { do in detail to improve } \\
\text { this stage of life. }\end{array}$ & \\
\hline I think I'm good, according to me. & $\begin{array}{l}\text { If it's a good thing or not. } \\
\text { What benefits retirement brings because in } \\
\text { some cases people fall into depression and } \\
\text { because other people do not want to retire. } \\
\text { Is it really important to stop working } \\
\text { even if you still have the ability? }\end{array}$ & $\begin{array}{l}\text { Why retirement is not a } \\
\text { favorable stage for some } \\
\text { people, what stages there are } \\
\text { and what can be learned } \\
\text { today. }\end{array}$ & $\begin{array}{l}\text { If the place where a } \\
\text { person works can put } \\
\text { off retirement or not. }\end{array}$ \\
\hline $\begin{array}{l}\text { Learn about retiree organizations, } \\
\text { opportunities to learn and conferences, } \\
\text { contacts and study groups. }\end{array}$ & $\begin{array}{l}\text { How I can make financially if I proceed } \\
\text { with the administrative process? } \\
\text { Where can a retiree go to get information? }\end{array}$ & & \\
\hline
\end{tabular}

Table 7.

Lessons learned after the conference.

\begin{tabular}{|c|c|c|c|}
\hline Retirees & Retirees' relatives & Pre-retirees & Relatives of pre-retirees \\
\hline $\begin{array}{l}\text { What I should do to } \\
\text { organize my life more. }\end{array}$ & $\begin{array}{l}\text { It is important to be prepared to face this stage } \\
\text { of life and this is the best way to cope with it. } \\
\text { It is necessary to make a plan on how to spend } \\
\text { free time pleasantly. }\end{array}$ & $\begin{array}{l}\text { What should I plan for in my new } \\
\text { phase of life and how to live it } \\
\text { with ease and acceptance. }\end{array}$ & \\
\hline $\begin{array}{l}\text { How I should take care of myself more. } \\
\text { Being retired is being relaxed, enjoying } \\
\text { myself with my health and retirement. } \\
\text { I have several choices of what to do. }\end{array}$ & Trying to adjust to life in retirement & $\begin{array}{l}\text { Retirement is a personal } \\
\text { individual process. }\end{array}$ & \\
\hline Retirement is very important. & $\begin{array}{c}\text { I did not have enough information before. It } \\
\text { is hard to assimilate and I need time discuss } \\
\text { it with my husband and to reaffirm it. } \\
\text { The actions and reactions we can have during } \\
\text { pre-retirement and retirement. }\end{array}$ & $\begin{array}{l}\text { In order to achieve the required } \\
\text { balance: health care, family, } \\
\text { social networks, spirituality } \\
\text { and altruism. }\end{array}$ & $\begin{array}{l}\text { I learned a lot more about } \\
\text { retirement than I imagined. What the } \\
\text { effects of retirement are on people } \\
\text { and what it may cause. }\end{array}$ \\
\hline $\begin{array}{l}\text { The privilege of having a } \\
\text { paid retirement. } \\
\text { Tragedy of } 93 \% \text { without protection }\end{array}$ & $\begin{array}{l}\text { A retiree is worried months before } \\
\text { reaching the end of this stage of life. } \\
\text { Retirees have different ways to view it. }\end{array}$ & & $\begin{array}{l}\text { I liked it because I know how to } \\
\text { conduct myself towards my partner. }\end{array}$ \\
\hline
\end{tabular}

indicated that after participating in the conference, they wanted to take better care of themselves, find options for new activities, live a little more socially, organize their life, stay active and help the disadvantaged.
It also coincides with Pick et al. (2010) that a brief intervention program, such as awareness through interactive lectures, has results comparable to longer programs but at a lower cost. For example, in this study, family members of retirees agreed 
Table 8.

Expectations after the conference.

\begin{tabular}{|c|c|c|c|}
\hline Retirees & Retirees’ relatives & Pre-retirees & Relatives of pre-retirees \\
\hline Dedicate a little more to my social life & Prepare to retire peacefully & & $\begin{array}{l}\text { Appreciate and make more effort to } \\
\text { the work of retirement. } \\
\text { Understand it better and do it all with dialogue } \\
\text { and agreeing and taking things more calmly. }\end{array}$ \\
\hline $\begin{array}{l}\text { How to assimilate personal crisis of not } \\
\text { being the breadwinner } \\
\text { How to help the } 93 \% \text { unprotected retirees }\end{array}$ & $\begin{array}{l}\text { What readings are recommended } \\
\text { to continue self-taught training? }\end{array}$ & $\begin{array}{l}\text { Knowing what data were } \\
\text { found in this study in } \\
\text { which we participated. }\end{array}$ & \\
\hline \multirow[t]{2}{*}{$\begin{array}{l}\text { Continue just as I am } \\
\text { Continue to be active }\end{array}$} & Nothing & & \\
\hline & $\begin{array}{l}\text { I wish I had information like advice } \\
\text { on the procedures to follow during } \\
\text { this administrative process. }\end{array}$ & $\begin{array}{l}\text { The economic expectations } \\
\text { I will face in retirement. }\end{array}$ & \\
\hline $\begin{array}{l}\text { Retirement should come in stages } \\
\text { and last about a year to become final. }\end{array}$ & Having a retirement & & \\
\hline
\end{tabular}

Table 9.

Reflections after the conference.

\begin{tabular}{|c|c|c|c|}
\hline Retirees & Retirees' relatives & Pre-retirees & Relatives of pre-retirees \\
\hline $\begin{array}{l}\text { If I planned my retirement I could live happily. } \\
\text { I was very happy to retire because I did } \\
\text { not have the pressure of a boss pressuring me. } \\
\text { Now I'm happy. But it was very hard to retire. } \\
\text { I had relapses. }\end{array}$ & $\begin{array}{l}\text { I want to get to retire and be as } \\
\text { happy as my grandmother. } \\
\text { I am thankful for my husband's } \\
\text { retirement because we are more united. } \\
\text { This is the happiest time of my life. }\end{array}$ & $\begin{array}{l}\text { I am a few years away from } \\
\text { retirement. The information } \\
\text { I received helped me to } \\
\text { understand my colleagues } \\
\text { who are retiring. }\end{array}$ & $\begin{array}{l}\text { I want my mom to retire to spend } \\
\text { more time at home relaxed. } \\
\text { I have to put up with my } \\
\text { husband who is nervous and } \\
\text { restless but I'll bear it. }\end{array}$ \\
\hline $\begin{array}{l}\text { I'm going to take the opportunity } \\
\text { to retire gradually. }\end{array}$ & $\begin{array}{l}\text { Retirement is a very difficult time in life } \\
\text { and we must acquire the knowledge } \\
\text { necessary to cope with it. You should } \\
\text { not wait to retire to do what you want. }\end{array}$ & $\begin{array}{l}\text { I feel uncertain because I do } \\
\text { not know how I will do. I want to } \\
\text { have time to work, rest and spend } \\
\text { more time with my family. }\end{array}$ & \\
\hline $\begin{array}{l}\text { I'm still working and I feel nothing. } \\
\text { I resented anything. }\end{array}$ & I have no opinion. & & \\
\hline $\begin{array}{l}\text { When I retired, I planned but nothing happened } \\
\text { as I expected. But I still think you need to plan. }\end{array}$ & $\begin{array}{l}\text { I feel frustrated because I will } \\
\text { never retire because I am a housewife. }\end{array}$ & & \\
\hline
\end{tabular}

on the importance of making a plan and preparing. Likewise, they were empathetic in recognizing that pre-retirees lived worried months beforehand about due to the administrative procedures and economic expectations. Relatives of adults approaching retirement age said that with a sensitivity strategy they could understand their partner better and be aware of planning for retirement together.

Finally, it is consistent with eQual (2011) in that communication is a tool that can help people take control of their own lives, raise critical awareness and generate practices of solidarity and active engagement with changing mindsets, attitudes or practices. In the case of the retired woman with problems to retire from work, she decided she would take the opportunity to retire gradually, because it was her right. Also, another retiree said that although his plan did not work out $100 \%$, he believed in the benefits of planning. Another acknowledged how hard it was for him to adapt to retirement.

\section{Conclusion}

The objectives of the study were met. We analyzed the experiences, lessons learned and expectations before and after the sensitizing conference.

Generally speaking, the experiences of older retirees, pre-retirees and their relatives were heterogeneous. Women's marital status was an influence factor (widows were happier than the single woman) as it was the presence of grandchildren, gender and education level in the case of preretirement (the male had negative experiences), and work activities (the retirees with informal employment were happier than the retired male who stayed at home).

The couples' relationship was affected most, both positively and negatively. Hence there is a need to engage the couple in preparation strategies, especially if the retiree is the male, whether to improve relationships or promote independence between them.

Previous knowledge was similar among all families although it was scarce. People asked for protocols with indications on how to act in the retirement and preretirement stages in order to help themselves and their families.

After the conference, retired people were aware of their problems and wanted to improve their lives. They were able to precisely express their needs about physical and social health. Retired people became aware of the need to take better care of themselves, to be at peace, to incorporate new activities, to organize their life, and to increase their social life, and of their right to have a phased retirement, to help other disadvantaged retirees and to work while they are no longer the family breadwinner.

Retirees' family members realized that retirees become wor- 
ried months before reaching the end of their working life stage. Retirement does not always mean wellbeing since retirees have different ways to view it, they need to plan and prepare to spend free time pleasantly and they need to have a life after retirement.

People close to retirement were sensitized about the need to plan for the new stage, have a positive attitude, take care of their health, their family, and their spirituality, increase their social networks and incorporate altruistic activities. Their new expectations were to have more information about economic issues.

Relatives of people nearing retirement realized the importance of being tolerant and understanding their relatives and expressed a desire to communicate and appreciate them.

The phenomenological method was suitable for learning the people's experiences. The semi-structured interviews and the SQA-E tools were simple, cheap and effective for the purposes of this study.

The study was limited to the stories of the participants who did not mention sexuality, addictions or deep fears. It is suggested that retirees and those who are close to retirement should accept invitations to participate in sensitivity strategies which are useful for them to become aware of their problems and make them want to take the initiative to improve their lives.

Family members of retired and pre-retired people are also encouraged to accept invitations to participate in sensitivity strategies because they will get information enabling them to understand and appreciate their families, especially in the case of wives who are homemakers.

The researchers continuously propose to offer systematic interventions with a sound theoretical basis in preparation for retirement.

We propose that educational and health institutions as well as employers and union leaders should promote and support the actions of preparing for retirement.

\section{Acknowledgements}

The authors are very grateful to the participants for sharing their experiences and life lessons with us.

\section{REFERENCES}

Aguilera, M. A., \& Torres, T. M. (2008). Vivencias de jubilación y prejubilación en odontólogos. Revista de Salud Pública y Nutrición, 9, $1-9$.

Aguilera, M. A., Acosta, M., \& Pozos, B. E. (2010). Evaluación de las intervenciones socioeducativas. México: Editorial Página 6.

Asociación Médica Mundial (2008). Declaración de Helsinki: Principios éticos para las investigaciones médicas en seres humanos. Korea.

Atchley, R. C. (1971). Retirement and leisure participations: Continuity or crisis? The Gerontologist, 11, 13-17.

http://dx.doi.org/10.1093/geront/11.1_Part_1.13

Casanova, M. A. (1999). Manual de evaluación educativa. España: Editorial La Muralla S. A.

Castillo, S., \& Cabrerizo, J. (2004). Evaluación de programas de intervención socioeducativa, agentes y ámbitos. España: Pearson Prentice Hall.

Chicharro, R., \& Maza, J. (2008). Programas de educación y sensibilización. Tiempo de Paz, 89, 153-156.

De las Heras, J. (2004). La preparación para la jubilación: Proyecto madurez vital. Congreso Nacional de Organización de Mayores. Madrid: Taurus.
Delgado, D., Aguilera, M. A., Delgado, F., \& Rug, A. (2012). The experience of miners relocated to alternative positions due to silicosis in the Andean of Codelco, Chile, 2010. SHAW, 3, 140-145.

eQual. (2011). Módulo II: La sensibilización como estrategia de cambio. Andalucía: Iniciativa Equal.

Gleiber, K., \& Hege, M. (1997). Acción socioeducativa. Modelos. Métodos. Técnicas. Madrid: Narcea, S. A. de Ediciones.

Guba, E. G., \& Lincoln, I. S. (1989). Fourth generation evaluation. Thousand Oaks, CA: Sage.

Husserl, E. (1972). Ideas relativas a una fenomenología pura y a una filosofía fenomenológica. México: Fondo de Cultura Económica.

Knowles, M. (2006). Andragogía el aprendizaje de los adultos. México: Editorial Alfaomega.

Lanigan, R. (1997). Capta versus data: Método e evidencia em comunicolgia. Trad. C. H. Kristensen. Psicología: Reflexao e Crítica, 10, 17-45. http://dx.doi.org/10.1590/S0102-79721997000100004

Limón, M. (1993). La preparación a la jubilación: Nueva ocupación del tiempo. Revista Complutense de Educación, 4, 53-67.

Madrid, G., \& Garcés F. (2000). La preparación para la jubilación: Revisión de los factores psicológicos y sociales que inciden en un mejor ajuste emocional al final del desempeño laboral. Anales de Psicología, 16, 87-98.

Maffesoli, M. (1997). Elogio de la razón sensible. Una visión intuitiva del mundo contemporáneo. Barcelona: Paidós Studio.

Merleau-Ponty, M. (1985). Fenomenología de la percepción. Barcelona: Planeta de Agostini S. A.

Moragas, R., Rivas, P., Cristofol, R., Rodríguez, N., \& Sánchez, C. (2006). Estudio: Prevención dependencia. Preparación para la jubilación-Dos. Barcelona: Grupo Investigación Envejecimiento GIE, Editorial Parc Cientific de Barcelona.

Morra, L. E., \& Friedlander, A. C. (2001). La evaluación mediante estudios de caso. Washington DC: Banco Mundial.

Morse, J. M., \& Field, P. A. (1995). Qualitative research methods for health professionals. Thousand Oaks, CA: Sage.

Organización de las Naciones Unidas (2003). Declaración política y plan de acción internacional de Madrid sobre el envejecimiento. Segunda asamblea mundial sobre el envejecimiento en Madrid, España del 8 al 12 de abril de 2002. Nueva York: Naciones Unidas.

Patton, M. Q. (1987). How to use qualitative methods in evaluation. Thousand Oaks, CA: Sage.

Patton, M. Q. (1990). Qualitative evaluation and research methods. London: Sage.

Pérez, A., Padilla, P., Loría, J., Herrera, N. J., Ortiz, S., Girón, A. T., \& Villafranca, R. M. (2006). Proyecto de vida posterior a la jubilación en el personal de enfermería de un hospital de segundo nivel. Revista Cubana de Enfermería, 22, 1-11.

Pérez, G. (1994). Investigación cualitativa: Retos e interrogantes. Madrid: Muralla.

Pérez, G. (2003). Pedagogía social. Educación social. Madrid: Narcea, S. A. de Ediciones.

Pick, S., Leenen, I., Givaudan, M., \& Prado, A. (2010). Yo quiero, yo puedo...prevenir la violencia: Programa breve de sensibilización en el noviazgo. Salud Mental, 33, 153-160.

Rodríguez-Sedano, A., \& Solés-Elizalde, M. A. (2008). Integración, familia y solidaridad: Vías de intervención en pedagogía social. Teoría de la Educación, 11, 121-137.

Sandoval, C. C. (2002). Investigación cualitativa. Colombia: Composición Electrónica ARFO Editores e Impresores Ltda.

Skoknic, V. (1998). Efectos de la preparación psicológica para la jubilación. Revista Intervención Psicosocial, 7, 155-168.

Stake, R. E. (1995). The art of case study research: Perspectives on practice. Thousand Oaks, CA: Sage.

Taylor, S. J., \& Bogdan, R. (1992). Introducción a los métodos cualitativos de investigación. Barcelona: Paidós.

Wilson, H. S., \& Hutchinson, S. A. (1991). Triangulation of qualitative methods: Heideggerian hermeneutics and grounded theory. Qualitative Health Research, 1, 263-273. http://dx.doi.org/10.1177/104973239100100206

Yin, R. K. (1989). Case study research: Design and methods. Applied social research methods. Thousand Oaks, CA: Sage. 